\title{
Article
}

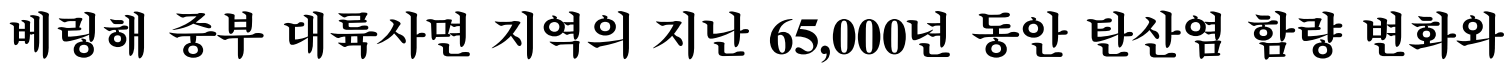 Dansgaard-Oeschger 사건들}

\author{
김성한 · 김부근 ${ }^{*}$ Takuya Itaki · 신혜선 \\ 부산대학교 지구환경시스템학부 \\ (609-735) 부산광역시 금정구 장전동 산 30
}

\section{Variation of Calcium Carbonate Content and Dansgaard-Oeschger Events in the Continental Slope of the Central Bering Sea during the Last $65 \mathrm{Kyr}$}

\author{
Sunghan Kim, Boo-Keun Khim*, Takuya Itaki, and Hye Sun Shin \\ Division of Earth Environmental System \\ Pusan National University, Busan 609-735, Korea
}

\begin{abstract}
A piston core (MR06-04 PC23A) collected from the northern continental slope in the central Bering Sea has recorded the high-resolution millennial-scale variation of calcium carbonate $\left(\mathrm{CaCO}_{3}\right)$ content during the last $65 \mathrm{kyr}$. An estimation of the age of the core sediments was carried out by using the lithologic correlation of the deglacial laminated layers with a neighboring core (HLY02023JPC), complementing the last appearance datum of both Lychnocanoma nipponica sakaii (54 kyr) and Amphimelissa setosa (85 kyr). The probable age of core MR06-04 PC23A was approximately younger than $65 \mathrm{kyr}$. Two distinct events of a significant increase of $\mathrm{CaCO}_{3}$ in the deglacial laminated sediments clearly correspond to MWP1A and MWP1B in the Bering Sea (Gorbarenko et al. 2005) and to T1ANP and T1BNP in the North Pacific (Gorbarenko 1996). These pronounced peaks of $\mathrm{CaCO}_{3}$ contents result from the elevated carbonate production in the surface water and the subsequent weakened dilution due to terrestrial input, along with an enhanced oxygen minimum zone. The $\mathrm{CaCO}_{3}$ contents are low $(\sim 2 \%)$ during the last glacial period mainly because of a low carbonate production caused by an expanded sea-ice cover and an increased dilution by terrigenous particles due to their closer distance to the continent during the sealevel low stand. The occurrence of seven distinct $\mathrm{CaCO}_{3}$ peaks in core MR06-04 PC23A is remarkable during MIS 3 and MIS 4, and they most likely correlate to the short-term millennial Dansgaard-Oeschger events.
\end{abstract}

Key words : calcium carbonate, Dansgaard-Oeschger events, deglaciation, paleoclimate, Bering Sea

\section{1. 서 론}

현재 많은 과학적 관심과 정책적 결정에 영향을 주고 있는 온실가스 증가에 따른 지구온난화는 인간 활동의 결

\footnotetext{
*Corresponding author. E-mail : bkkhim @pusan.ac.kr
}

과로 보고되었다(Griffin 2003). 하지만 온실 가스 중에 하 나인 이산화탄소의 대기 농도는 인간 활동이 영향을 미치 기 전에는 자연적인 증가와 감소를 반복해 왔다(Petit et al. 1999). 이러한 과거의 대기 이산화탄소의 농도 변화는 그린랜드 빙하(GRIP) 코아에서 분석된 결과에 의해 밝혀 졌으며, 이산화탄소의 대기 농도는 빙하기-간빙기에 따라 
변화하였다(Barnola et al. 1987). 그린랜드 빙하 코아에서 분석된 산소동위원소 자료에 의하면 전 지구적인 빙하기 -간빙기의 장기적인 기후변화와는 다르게 천 년 단위의 급 격한 기후변화도 뚜렷하게 관찰되었다(Dansgaard et al. 1993). 이러한 단주기의 기후변화는 현재 진행되는 지구 온난화의 예측 연구에 중요한 정보를 제공할 수 있기 때 문에 해양에 기록된 단주기 형태의 기후변화에 대한 연구 가 많은 해역에서 수행되고 있다(Bond et al. 1993; Bond and Lotti 1995; Hendy and Kennett 2000; Kiefer et al. 2001).

그린랜드 빙하 코아에서 분석된 산소동위원소 자료에 의하면, 지난 마지막 빙하기를 포함하여 약 110,000 년 전 에서 23,000 년 전 사이에 일련의 매우 급격한 변화들이 관찰되었고, Dansgaard et al.(1993)은 이러한 23개의 사 건을 Dansgaard-Oeschger (D-O) 사건으로 명명하였다. D-O 사건들은 빙하기동안 북반구에서 천 년 단위로 대기 온도가 급격하게 증가를 했다가 하강하는 양상을 보여 주 며, 이 기간 동안 대기의 연평균 온도 변화는 적어도 $5^{\circ} \mathrm{C}$ 이상으로 계산되었다(Johnsen et al. 1995). 그린랜드의 빙 하 시추코아에서 관찰된 D-O 사건은 해양에서도 그 기록 들이 보고되고 있다. Behl and Kennett(1996)는 해양퇴적 물에서 관찰한 생물교란지수(bioturbation index)를 기준으 로 북동태평양의 산타바바라 분지에서 층리가 잘 보존된 시기들이 D-O 사건의 아간빙기(interstadial)들과 일치한다 고 제안하였다. Hendy and Kennett(2000)는 북동태평양에 서 시추된 ODP Site 893에서 D-O 사건이 나타나는 아빙 기(stadial) 동안에는 아극성 캘리포니아 해류(subpolar California Current)의 영향을 많이 받았고, 아간빙기동안 에는 아열대 캘리포니아반류(subtropical countercurrent)의 영향을 많이 받았으며, 이러한 급격한 기후변화로 인해 표 층 해수의 특성과 해수 순환이 갑작스럽게 변화되었다고 설명하였다. 한편, 북서태평양의 ODP Site 883 연구에서 는 Marine Isotope Stage(MIS; Martinson et al. 1987) 3 동 안의 천 년 단위 주기의 온난화 변화들이 D-O 사건의 아 빙기 시기와 일치한다고 발표되었다(Kiefer et al. 2001). 이것은 전 지구적 대기 순환에 의한 열수송으로 인해 북반 구의 각 지역에서 비슷한 양상을 보일 것이라는 예측이 빗 나간 것이었다. 그리고 북대서양은 춥고, 북서태평양은 따 뜻한 반대 양상은 전 지구 해류 순환의 변동에 의해 설명 되어질 수 있다. D-O 사건의 아빙기에 북대서양심층수 (North Atlantic Deep Water)의 약화 또는 소멸이 차가운 태평양 심층수의 용승을 감소 또는 중단시키기 때문에 이 시기 동안 북서태평양의 표층수가 짧은 기간 동안 따뜻해 졌다.

베링해는 전 지구적 심층 순환의 마지막 도달지역에 위 치하고, 북극해를 통하여 북태평양과 북대서양을 연결하
는 해역이라는 점에서 매우 중요한 지리적 위치에 있다. 1971년도에 DSDP Leg 19가 베링해의 일부지역에서 시추 되었음에도 불구하고(Scripps Institution of Oceanography 1973), 현재 우리가 알고 있는 베링해에 대한 고해양학적 역사와 자료는 많이 부족하다. 이러한 이유는 그 당시 DSDP 시추의 주목적이 퇴적물에 대한 정보 획득보다는 퇴적층의 두께 파악에 있었기 때문이다(Takahashi 1998). 베링해의 탄산염 포화수심(carbonate saturation depth)은 약 $500 \mathrm{~m}$ 로 매우 낮기 때문에(Feely et al. 2002) 탄산염 이 풍부한 북대서양의 고위도 지역과는 다르게 베링해에 서 수행된 기존의 고해양학적 연구들은 규조(Sancetta 1983; Sancetta et al. 1985)와 방산충(Morley and Robinson 1986)과 같은 주로 규산질의 미화석을 이용하였다.

2000 년 이후에 북극해와 북태평양을 연결하는 통로 (gateway)로서 베링해에 대한 관심들이 증가하여 고해양 학적 연구들이 많이 수행되었다(Takahashi 2005). Katsuki and Takahashi(2005)은 규조 종분석을 이용하여 제 4기 동 안 베링해의 생산성, 해빙 그리고 표층 해류 순환의 계절 적 변화를 복원하였다. 예를 들어, 규조 퇴적률과 종 구성 의 지역적 차이는 해빙의 분포에 따라서 변화되는 수괴들 의 공간적 이동 때문이라고 해석하였다. 마찬가지로 Okazaki et al.(2005)도 지화학적 자료들을 이용하여 베링 해의 제 4 기동안 표층해수의 생산성이 빙하기에 비하여 현세 간빙기에 증가하였다고 발표하였다. Gorbarenko et al.(2005)은 베링해의 남쪽에 위치한 보우어스 해령 (Bowers Ridge)에서 MIS 3 시기의 천 년 단위의 환경 변 화를 연구하였다. 그들은 지난 마지막 빙하기에서 높은 탄 산염의 값, 유공충의 낮은 산소동위원소 값, 그리고 미화 석 분석 결과가 D-O 사건의 아간빙기 시기와 일치한다고 주장하였지만, 시추코아에서 분석된 자료들의 해상도가 낮기 때문에 D-O 사건들이 뚜렷하게 관찰되지는 않았다.

이 연구에서는 베링해 중앙 지역의 대륙사면에서 채취 한 피스톤 코아 퇴적물에서 고해상의 탄산염 함량을 분석 하였다. 주요 연구목적은 빙하기-간빙기에 따른 탄산염 함 량 변화를 설명하고 마지막 빙하기 동안 관찰되는 천 년 단위의 D-O 사건과 베링해 중부지역의 단주기 고해양학 적 변화와의 관련성을 해석하는 것이다.

\section{2. 연구 지역}

베링해는 동쪽으로 알라스카, 남쪽으로 알류샨 열도, 그 리고 서쪽으로는 캄차카 반도와 시베리아에 의해서 둘러 싸여져 있고 북쪽으로는 베링해협을 통해 북극해로 연결 된다(Fig. 1). 환태평양 지역에서 가장 넓은 반 폐쇄형 연 해(marginal sea)인 베링해의 면적은 $2.29 \times 10^{6} \mathrm{~km}^{2}$ 이고 부피는 $3.75 \times 10^{6} \mathrm{~km}^{3}$ 로, 지중해와 남중국해에 이은 세계 


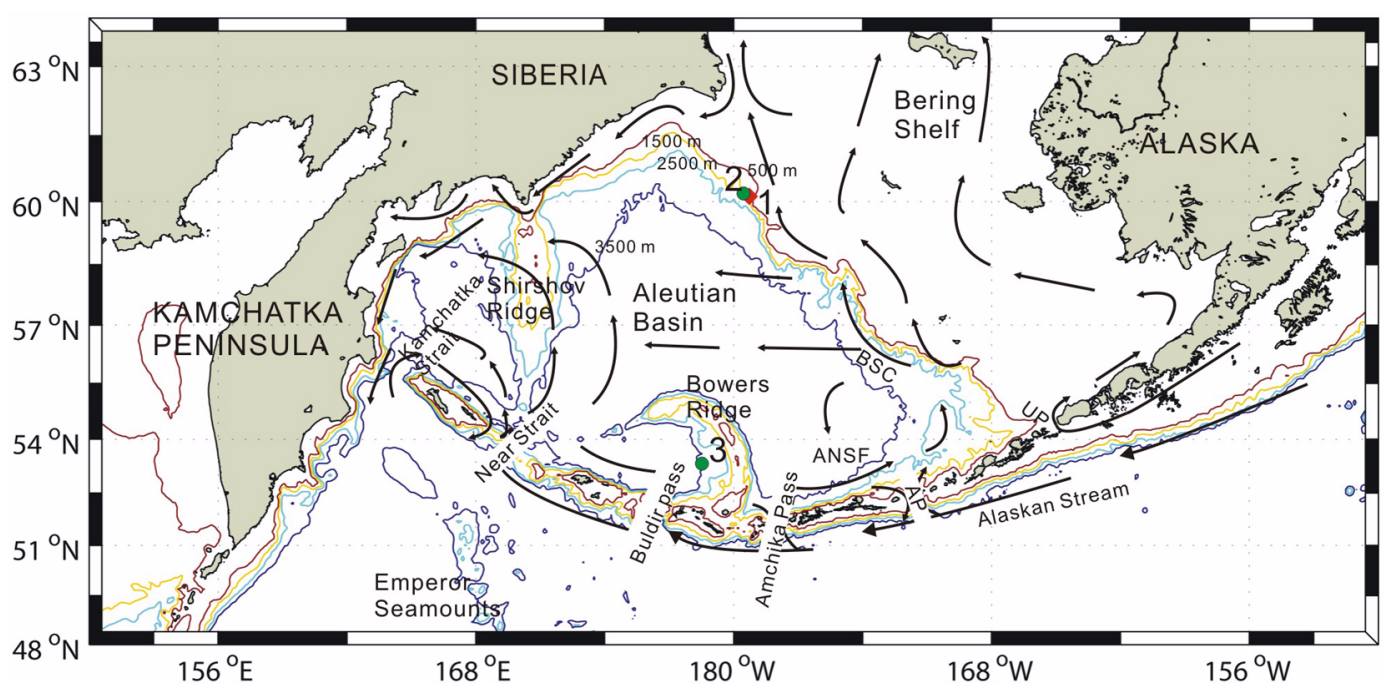

Fig. 1. Schematic bathymetry of the Bering Sea with the collection sites of Cores MR06-04 PC23A (1), HLY02023JPC (2), and GC-11 (3). Arrows show the direction of major surface currents. BSC: Bering Slope Current, ANSF: Aleutian North Slope Current, AP: Amutka Pass, UP: Unimak Pass.

에서 세 번째로 넓은 연해이다(Hood 1983). 베링해의 반 정도는 수심이 $200 \mathrm{~m}$ 보다 낮은 대륙붕으로 구성되어 있 다. 대부분의 대륙붕은 브리스톨 만에서부터 베링해협에 이르는 베링해의 동쪽 및 북동쪽에 위치해 있다. 베링해의 남쪽 지역에는 수심이 $3500 \mathrm{~m}$ 이상인 분지가 존재한다 (Fig. 1). 이러한 분지에 두 개의 해령이 위치한다. 하나는 알류산 열도에서 북쪽으로 이어지는 보우어스 해령이고, 다른 하나는 캄차카에서 알류산 분지까지 연결되는 시르 쇼브 해령(Shirshov Ridge)이다.

베링해의 표층 순환은 북태평양의 아극 순환 시스템에 의해 영향을 받는다(Fig. 1). 베링해의 표층에는 상대적으 로 낮은 염분 $(<34.0 \mathrm{psu})$ 과 낮은 수온 $\left(4-12^{\circ} \mathrm{C}\right)$ 그리고 강 한 염분약층 $(150-200 \mathrm{~m})$ 을 가진 수괴가 반시계방향으로 흐른다(Favorite et al. 1976). 이러한 표층 수괴는 알류산 열도를 따라서 서쪽으로 흐르는 알라스카 해류에 의해 영 향을 받는다(Stabeno et al. 1999). 한편, 베링해는 전 지구 심층 순환의 마지막 지점에 위치하고 있다. 따라서 북태평 양 심층수(North Pacific Deep Water)가 캄차카 해협(수심 약 $3000 \mathrm{~m}$ )을 통해서 베링해로 유입되어 북쪽과 동쪽으로 흐른다(Stabeno et al. 1999). 대서양에서 기원한 북태평양 심층수는 연대가 오래되었기 때문에 탄산염의 보존이 매 우 열악한 수괴이다.

베링해의 여름철에는 알류샨 저기압이 거의 존재하지 않고, 북태평양 고기압권의 북쪽과 아시아 대륙에 형성된 저기압권 사이에 놓이게 된다. 그 결과, 강한 바람이 형성 이 되지 않고(Niebauer 1998), 강한 태양열로 인해 표층의 성층화가 일어난다(Katsuki and Takahashi 2005). 반면, 겨울에는 아시아 대륙에 시베리아 고기압이 형성되고, 베
링해를 포함한 북태평양에는 알류샨 저기압이 형성된다. 겨울철의 기압차가 더 커지기 때문에 베링해에 강한 북서 계절풍이 불어온다. 그리고 이 북서 계절풍이 겨울철의 약 한 태양복사에너지 때문에 상대적으로 더욱 강하게 되어 여름철에 형성된 밀도약층을 파괴하고, 얕은 대륙붕의 바 닥까지 수층의 혼합을 야기시킨다(Niebauer 1998).

대부분의 겨울동안 베링해의 북동쪽을 구성하는 대륙붕 의 $75 \%$ 정도가 해빙에 의해 덮여지는 반면에, 여름에는 강한 태양열로 인해 해빙이 발달하지 않는다(Niebauer 1998). 베링해의 해빙은 보통 11월에 발달하기 시작하고, 봄이 되면서 4월 중순부터 녹기 시작하다 보통 5월이 되 면 완전히 녹는다(Khen 1999). 이러한 계절적인 해빙의 발달과 소멸은 평균 약 $1700 \mathrm{~km}^{2}$ 로 다른 어느 극지역과 아극지역 보다 넓게 나타난다. 그리고 이러한 해빙의 극심 한 연간 변동은 태양복사에너지가 낮고, 강한 계절풍이 부 는 겨울에 의해 영향을 받는다(Niebauer 1998).

\section{3. 재료 및 방법}

길이 $18 \mathrm{~m}$ 의 코아 $\mathrm{MR06-04} \mathrm{PC} 23 \mathrm{~A}$ 는 베링해의 중앙 대륙사면 $\left(60^{\circ} 09.52^{\prime} \mathrm{N}, 179^{\circ} 27.82^{\prime} \mathrm{W}\right.$, 수심 $\left.1002 \mathrm{~m}\right)$ 에서 R/V Mirai호에 의해서 2006년에 피스톤 코아를 이용하여 채취되었다(Fig. 1). 코아는 선상에서 절개되어 암상의 특 성을 기재한 후에 부시료를 채취하여 냉장 보관한 후에 부산대학교 실험실로 운반되었다.

코아 퇴적물은 부산대학교 공동실험실습관에서 동결 건 조된 후, 아게이트 몰을 이용하여 분말화되었다. 퇴적물의 탄산염 $\left(\mathrm{CaCO}_{3}\right)$ 함량은 약 $5 \mathrm{~cm}$ 간격으로 총 385 개가 분 
석되었다. 퇴적물 분말 시료를 무기탄소분석기 $\left(\mathrm{UIC} \mathrm{CO} \mathrm{CO}_{2}\right.$ Coulometer: Model CM5014)를 이용하여 총무기탄소 (Total Inorganic Carbon: TIC) 함량을 측정하였다. 산처리 모듈에서 퇴적물의 탄산염과 인산의 반응으로 탄산염의 용해에 의해 발생된 이산화탄소가 가스 유입에 의해 전량 분석 셀로 이동된다. 이 때, 전량분석 셀에는 모노에탄올 라민(monoethanolamine) 수용액이 담겨져 있고, 한 개의 색채 지시자가 들어있다. 이산화탄소는 정량적으로 이 용 액에 흡수되고, 모노에탄올라민과 반응하여 색채 지시자 를 퇴색시키는 적정이 가능한 강산(hydroxyethylcarbamic acid)을 형성한다. 이러한 적정은 자동으로 일어나며, 음극 단자에서 발생한 수산이온이 용액을 원래의 상태인 푸른 색으로 되돌려 놓게 된다. 이때 분석 셀 내 반응용액의 수 소이온농도 $(\mathrm{pH})$ 변화는 수소이온농도 지시용액의 색상변 화로 표현되며 광검출기가 이를 투과율 $(\% \mathrm{~T})$ 로서 검출한 다. 투과율이 증가하면 자동으로 전류가 발생하여 투과율 에 비례하여 염기를 발생시켜 이산화탄소의 흡수에 따라 발생된 산을 중화시키게 되며, 중화과정이 끝나고 용액이 원래의 색으로 돌아가면 전류발생이 중단되면서 적정이
끝나고, 발생한 전류량에 의해 시료 내 무기 탄소의 함량 을 정량하게 된다.

탄산염 함량은 총무기탄소 함량을 탄소에 대한 탄산염 의 비 $\left(\mathrm{CaCO}_{3} / \mathrm{C}\right)$ 인 8.33 을 곱하여 구하였다.

$$
\mathrm{CaCO}_{3}(\%)=\mathrm{TIC}(\%) \times 8.33
$$

\section{4. 결과 및 토의}

\section{연대 결정}

일반적으로 제 4 기 후기의 퇴적물 연대는 탄산염으로 구 성된 유공충을 이용하여 가속질량분석기(AMS)로 방사능 탄소동위원소 연대를 구하여 결정한다. 그러나 이 연구에 서는 방사능 탄소동위원소 연대가 아직 결정되지 않았기 때문에 암상대비를 이용하여 코아 MR06-04 PC23A의 연 대를 설정하였다. Cook et al.(2005)은 이번 연구지역인 베링해 중앙 대륙사면에서 피스톤 코아 HLY02023JPC $\left(60.128^{\circ} \mathrm{N}, 180.558^{\circ} \mathrm{E}\right.$, 수심 $\left.1132 \mathrm{~m}\right)$ 를 채취하여 연대를 발표하였다(Fig. 2). 상부 $410 \mathrm{~cm}$ 까지 코아 MR06-04

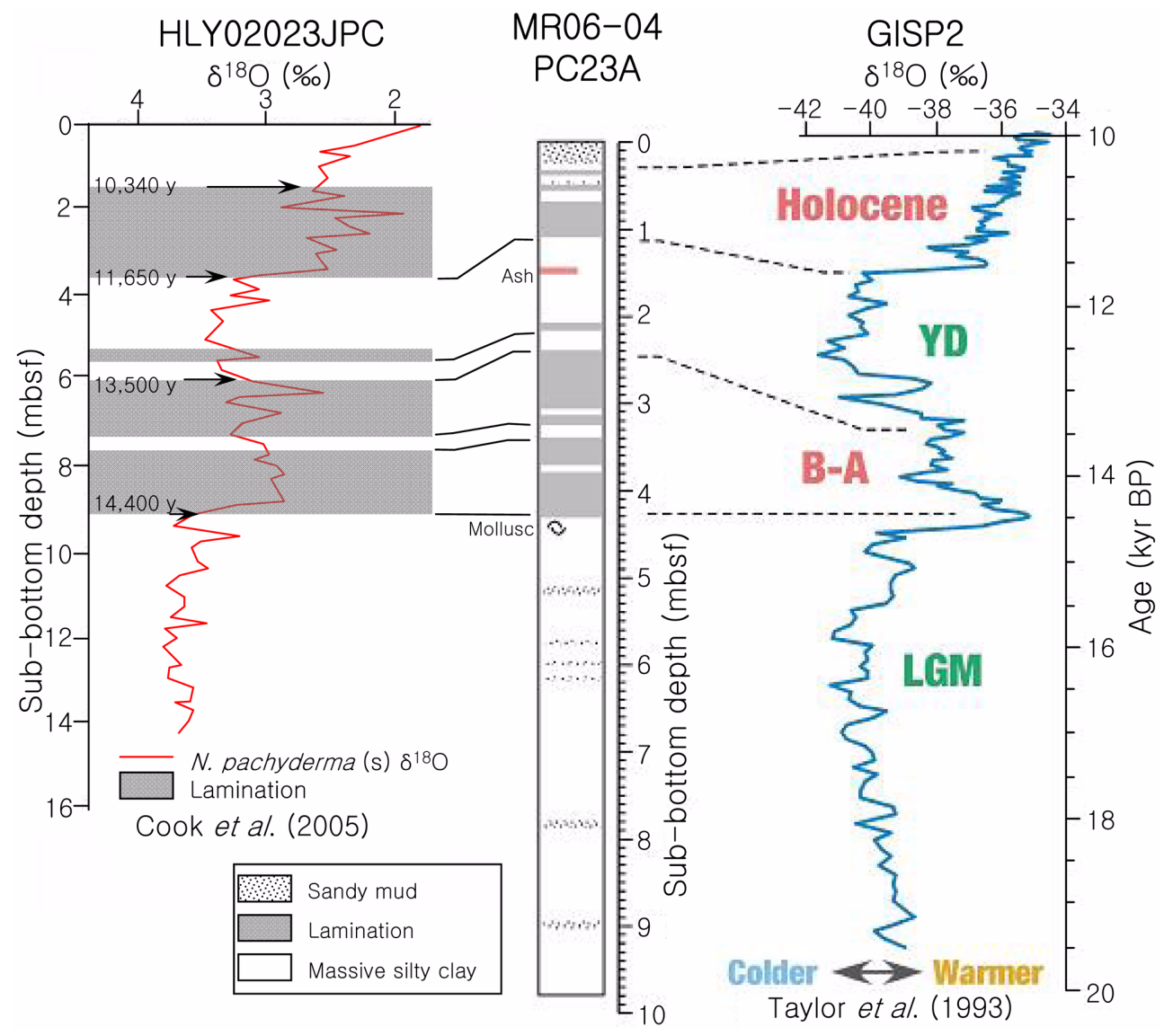

Fig. 2. Age estimate of the upper part of core MR06-04 PC23A by comparison with the deglacial laminated layers to the dated core HLY02023JPC (modified after Cook et al. 2005) and GISP 2 (Taylor et al. 1993). YD: Younger Dyras, B-A: Bølling-Ållerød, LGM: Last Glacial Maximum. 
$\mathrm{PC} 23 \mathrm{~A}$ 의 암상을 코아 HLY02023JPC와 비교하였다. 특 히, 코아 HLY02023JPC와 같이 짙은 올리브색과 연한 올 리브색을 띠며, 유공충과 규조가 많이 포함된 잘 발달한 엽리층(laminated layer)은 코아 MR06-04 PC23A의 상부 연대를 예측하는데 결정적인 지시자로 사용되었다. 그 결 과, 코아 MR06-04 PC23A의 상부 $1.07 \mathrm{~m}, 2.41 \mathrm{~m}, 4.29 \mathrm{~m}$ 가 각각 $11,650(10,900-11,920)$ cal. $\mathrm{yrBP}, 13,500(13,470-$ $13,810)$ cal. yrBP, $14,400(14,330-15,360)$ cal. yrBP에 상 응하는 것으로 나타났다(Fig. 2). 하지만, 이 경우, 비슷한 위치와 수심에도 불구하고 거의 2 배에 가까운 퇴적률의 차이를 보이게 되는데, 이는 코아 MR06-04PC23A가 수 심이 비교적 얕은 해저 언덕의 정상부에서 채취되었기 때 문이다. 그리고 움낙 고원과 보우어스 해령에서 획득된 코 아에서도 같은 기간 동안 코아 HLY02023JPC와 같은 엽 리층이 발견되었다(Cook et al. 2005). 이러한 점에서 볼 때, 코아 MR06-04PC23A의 암상대비에 의한 연대설정에 큰 무리가 없음을 시사해 준다. 코아 MR06-04 PC23A의 상부 연대가 약 $10 \mathrm{cal} . \mathrm{kyrBP}$ 로 예측되어 현세기간동안 낮은 퇴적률을 보이는 것은 피스톤 코아를 이용하여 코 아 채취 동안 발생되는 코아 상부의 손실에 의한 것일 수 있다.

방산충 Lychnocanoma nipponica (Nakaseko) sakaii Morley and Nigrini와 Amphimelissa setosa (Cleve)의 마 지막 출현(Last Appearance Datum)은 각각 약 54,000년 전과 약 85,000년 전으로 알려졌다(Itaki et al. 2007). 코아 MR06-04 PC23A의 하부 구간 $(14.27 \mathrm{~m})$ 에서 L. nipponica sakaii가 마지막으로 발견되었지만, A. setos $a$ 는 코아에서 발견이 되지 않았다. 이러한 방산충 출현의 생층서학적 연 대에 의하여 코아 MR06-04 PC23A의 하부의 가능한 최 대 연대(possible maximum age)가 지난 60,000년에서 70,000 년 사이로 정도로 추정된다. 이러한 연대를 가정하 면, 시대에 따라 퇴적률이 변화될 수 있지만 연구지역의 퇴적률이 일정했다고 가정한다면, 코아 MR06-04 PC23A 의 퇴적률은 약 $30 \mathrm{~cm} / \mathrm{kyr}$ 로 매우 높게 계산되고, 탄산염 함량 분석에 사용된 시료 구간은 약 $5 \mathrm{~cm}$ 로 200년 미만의 간격으로 천 년 단위의 기후 변화를 충분히 기록할 수 있 을 것으로 예측된다.

\section{탄산염 함량 변화}

코아 MR06-04 PC23A의 탄산염 함량 변화는 Fig. 3에 나타나 있다. 베링해는 일반적으로 규조의 높은 생산에 의 한 규질 연해(siliceous ocean)의 특성을 보이기 때문에 베 링해 퇴적물의 탄산염 함량은 평균 $2 \%$ 로 매우 낮게 보고 되었다(Honjo 1990). 그러나 이 연구에서 분석된 코아 MR06-04 PC23A의 탄산염 함량 변화는 최대 $8 \%$ 까지 높 은 값을 잘 보여주고 있다(Fig. 3). 코아 전체적으로 간헐

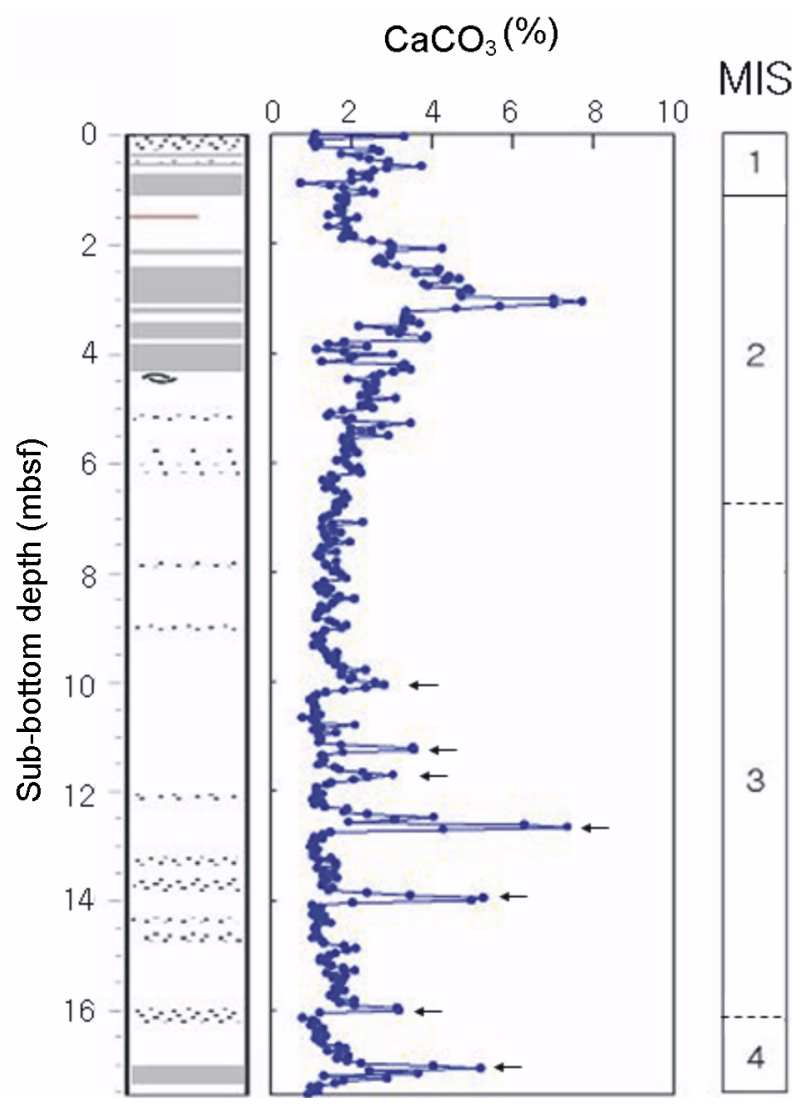

Fig. 3. Sediment lithology and variation of $\mathrm{CaCO}_{3}$ contents of core MR06-04 PC23A. Arrows indicate seven $\mathrm{CaCO}_{3}$ peaks during MIS 3 and MIS 4 . MIS boundaries were judged by the tentative age estimates based on Fig. 2 (refer to the text).

적인 피크를 제외하고는 대부분의 퇴적물에서 베링해의 일반적인 특징으로 약 $2 \%$ 의 탄산염 함량이 측정되었다. 코아 상부(0-4.29 m)의 현세전기(MIS 1)와 마지막 빙하 기의 후반은 두 개의 잘 발달 된 엽리층들이 상대적으로 높은 탄산염 함량을 보인다. 탄산염 함량이 높게 나타나는 두 개의 층은 Gorbarenko et al.(2005)이 베링해 남부지역 에서 연구한 core GC-11에서 보고한 MWP1B와 MWP1A 에 각각 해당된다. MWP1B의 연대는 $11 \mathrm{cal} . \mathrm{kyrBP}$ 이며 MWP1A는 $14.8 \mathrm{cal}$. kyrBP로 Cook et al.(2005)에서 측정 된 두 개의 엽리층의 연대와 잘 일치한다. 또한, 이러한 후 빙기에 나타나는 탄산염 함량이 높은 두 층은 북태평양의 코아에서도 나타나며 Gorbarenko(1996)은 각각 T1ANP 와 T1BNP로 명명하였다. 그리고 탄산염 함량이 높은 두 시기 사이의 낮은 탄산염 함량을 보이는 MIS 1 경계 전은 아마도 Younger Dryas 시기로 해석된다(Fig. 3). MIS 2의 마지막 최대 빙하기(Last Glacial Maximum) 구간(4.29$6.72 \mathrm{~m}$ )에는 탄산염의 함량과 그 변동이 매우 낮게 나타나 며, MIS 2기간동안 코아 하부에서 상부로 탄산염 함량이 
점진적인 증가를 보인다(Fig. 3). MIS 3과 MIS 4 기간 (6.72-17.53 m)에는 MIS 2의 하부와 마찬가지로 전반적으 로 낮은 탄산염 함량을 보이지만 높은 탄산염 함량을 보 이는 7개의 뚜렷한 피크가 관찰된다(Fig. 3). 이러한 탄산 염 피크들은 매우 짧은 시기동안 갑작스럽게 나타나며 약 $4 \%$ 에서 $8 \%$ 의 함량을 보인다. 탄산염 함량이 높은 7 개의 피크들 중에서 코아 하부의 약 $17 \mathrm{~m}$ 에서 나타나는 피크는 후빙기의 높은 탄산염 함량과 마찬가지로 엽리층이 나타 나는 점이 다른 6 개의 피크들과 비교된다.

해양에서 생물 기원 물질(탄산염과 생규소)의 공급은 표층 해양에서 서식하는 생물체가 탄산염이나 생규소를 얼마나 생산했느냐에 의해서 결정된다(Penrose 1982). 탄 산염의 경우 표층 해수의 일차생산자인 인편모조류나 동 물플랑크톤인 유공충에 의해 만들어지며, 생규소는 규조 또는 방산충에 의해서 생산된다. 따라서 이러한 생물 기원 물질 중에 일차생산자의 생산성은 성장에 필요한 영양염 의 이용정도와 관련이 된다. 표층에서 생성된 생물 기원 물질은 해저에 퇴적된 후에 다른 비생물 기원의 물질들과 혼합되어 그 함량이 변화된다(Penrose 1982). 육상에 가까 운 대륙사면이나 대륙대의 퇴적물은 주로 육성기원의 세 립 입자가 여러 경로를 통해서 운반되기 때문에 대륙연변 부 지역에서는 생물 기원 물질들이 많은 양의 육성 기원 물질에 의한 희석으로 인해 함량이 낮게 나타날 수도 있 다. 또한, 표층에서 생성된 생물 기원 물질들은 퇴적되기 전까지 그리고 퇴적된 후에 겪는 용해에 의하여 그 함량 이 변화된다. 규산염의 경우에는 해양의 상부에서 용해가 발생되며, 탄산염 용해는 일반적으로 수심이 깊어질수록 강하게 발생한다(Penrose 1982). 베링해의 탄산염 포화수 심은 약 $500 \mathrm{~m}$ 로 매우 낮기 때문에, 수심이 깊은 분지 퇴 적물의 경우 탄산염의 보존이 매우 어렵다(Feely et al. 2002).

후빙기 $(0-4.29 \mathrm{~m})$ 에는 해수면의 상승으로 인해 코아 MR06-04 PC23A가 채취된 지점과 주변 육지와의 거리가 멀어져서 육성 기원의 쇄설성 입자들의 공급이 빙하기에 비하여 감소했기 때문에 비생물기원 입자들에 의한 희석 효과가 약해졌을 것으로 추측된다. 그리고 기후가 점점 따 뜻해지고, 육상의 빙하가 녹으면서 공급되는 융빙수에 의 하여 해양으로 운반되는 영양염이 증가되어 표층 해수의 생산성을 증가시켰을 것이다. 퇴적물의 엽리층은 저층수 의 용존 산소 농도가 $5 \mu \mathrm{M}$ 이하 인 조건에서, 저서 생물 (burrowing macrofauna)의 교란이 없을 때 형성되는 것으 로 알려져 있다(Cook et al. 2005). 이 기간 동안 표층 해 수의 생산성 증가로 인해 많은 양의 유기물이 저층으로 공급되고, 이렇게 공급된 유기물의 분해에 의해 저층수의 용존 산소가 고갈되어 엽리층이 형성된 것으로 해석된다. Okazaki et al.(2005)는 이 기간에 퇴적된 퇴적층에 인편모
조류의 함량이 증가하였다고 보고하였다. 코아 MR06-04 $\mathrm{PC} 23 \mathrm{~A}$ 가 채취된 지역에서도 이 기간동안 인편모조류의 높은 생산성에 의하여 탄산염 함량이 증가한 것으로 해석 된다(Fig. 3). 코아 MR06-04 PC23A가 채취된 연구지역 의 수심은 북태평양 심층수의 영향이 없는 중층수의 위치 이지만, 일반적으로 대륙사면의 중층수가 위치한 수심에 는 용존산소최소층(Oxygen Minimum Zone)이 발달하는 특성을 보인다. 따라서 후빙기의 엽리퇴적층이 발달하는 기간에 용해의 효과가 변화했는지 현재의 자료만으로는 잘 알 수 없지만, 해수면 상승으로 말미암아 희석 효과의 감소와 표층 해수에서 생산성의 증가가 탄산염 함량 증가 에 더 큰 역할을 한 것으로 생각된다. 마찬가지로, 추운 기 후를 나타내는 Younger Dryas 시기에 낮은 탄산염 함량은 표층 해수에서 생산성이 감소한 결과로 예상된다.

MIS 2(4.29-6.72 m) 동안에는 해수면이 현재보다 약 $120 \mathrm{~m}$ 낮아져서(Fairbanks 1989), 베링해 대륙붕의 대부분 이 육지로 드러나고 북극해와 단절되는 지형적 변화를 격 게 된다. 해안선이 남서쪽으로 이동하면서 코아 MR06-04 $\mathrm{PC} 23 \mathrm{~A}$ 의 채취지점과 주변 육지와의 거리가 상대적으로 가까워져 육성 기원 물질 유입의 증가로 말미암아 강한 희석을 받았을 것으로 예상된다. 그러나 빙하기 동안 형성 된 해빙(sea ice)의 효과로 표층해류가 약화되어 육성 기 원 물질의 운반이 감소하였을 가능성도 배제할 수 없다. 하지만, 베링해에서 빙하기 동안 해빙이 형성될 때, 우세 한 북풍에 의해 해빙이 연안지역으로부터 남쪽으로 이동 되면서 빙호(polynyas)가 발달한다(Niebauer et al. 1999). 이 빙호에서는 대기와 해양 사이에 열교환이 높게 일어나 며 새로운 해빙이 형성되어 그 결과 염분이 상승하게 된 다(Maykut 1978). 따라서, 빙호 지역에서 낮은 온도와 높 은 염분의 해수가 증가된 밀도로 인해 가라앉으면서 주변 육상에서 공급된 쇄설성 입자들이 운반될 것으로 생각된 다. 한편, 빙하기 동안 해빙의 효과로 인한 베링해 표층 해 수의 생산성이 전반적으로 매우 감소하였을 것이다. 지난 마지막 빙하기 동안 해빙의 영향을 받지 않았던 베링해의 남쪽 보우어스 해령에서 시추된 코아들의 탄산염 함량도 매우 낮게 보고되었다(Gorbarenko et al. 2005; Katsuki and Takahashi 2005; Okazaki et al. 2005). 따라서 빙하기 동안 베링해 전역이 표층해양의 생산성은 해빙의 효과와 더불어 영양염의 공급이 줄어들어 온난한 현세에 비하여 감소한 것으로 생각된다. 해수면이 낮아진 빙하기 동안에 베링해의 탄산염보상수심(carbonate compensation depth) 의 위치에 대한 자료가 부족하기 때문에, 탄산염보상수심 에 의한 탄산염 용해의 효과가 어떻게 작용했는지 현재로 서는 파악하기 어렵다. 캄차카 해협(수심 약 $3000 \mathrm{~m}$ )을 통해 베링해로 들어오는 북태평양 심층수의 양이 변함에 따라 용해의 정도가 달라질 수 있다. 북태평양 심층수는 
연령이 오래되어 이산화탄소가 풍부하기 때문에 탄산염 을 잘 용해시키기 때문이다. 하지만, 연구지역의 수심을 고려한다면, 북태평양 심층수의 영향이 중요하게 작용하 지는 않았을 것으로 예상할 수 있다. 따라서, MIS 2 동안 의 탄산염 함량의 감소는 주로 생산성의 감소와 희석 효 과의 증가에 의해 조절되었다고 해석된다.

마지막 빙하기인 MIS 3과 MIS 4 시기(6.72-17.53 m)에 는 전반적으로 MIS 2와 마찬가지로 낮은 탄산염 함량을 보인다(Fig. 3). 하지만, 베링해에서 보고된 최근의 자료에 의하면 이 기간의 N. pachyderma (s)와 U. auberiana의 산 소동위원소 값이 MIS 2시기보다 더 낮다는 것은 이 시기 의 기후가 상대적으로 따뜻했음을 시사한다(Gorbarenko et al. 2005; Brunelle et al. 2007) 그리고, 전체적으로 낮 은 탄산염을 보이는 MIS 2와는 다르게 높은 탄산염 함량 을 보이는 7개의 뚜렷한 피크가 나타난다(Fig. 3). 높은 탄 산염 함량을 보이는 이 피크들은 시기적으로 매우 짧은
기간 동안 발생 된 것이다. MIS 2와 마찬가지로 상대적으 로 증가된 희석이나 감소된 표층 생산성에 의해서 낮은 탄산염 함량을 나타내지만, 이렇게 짧은 기간에 급격하게 높은 탄산염 함량을 보이는 것은 아마도 용해나 희석의 역할보다는 상대적으로 표층생산성의 급격한 증가로 인한 환경변화로 이해될 수 있다.

\section{베링해의 Dansgaard-Oeschger(D-O) 사건 기록}

베링해의 남쪽 보우어스 해령에서 시추한 코어와 움낙 고원(Umnak Plateau)에서 시추한 코아에서 MIS 3시기 동 안에 탄산염 함량이(2-4\%) 급격한 변화를 보인다고 보고 되었다(Okazaki et al. 2005). 마찬가지로 Gorbarenko et al.(2005)은 보우어스 해령에서 시추된 코아 GC-11 $\left(53^{\circ} 31^{\prime} \mathrm{N}, 178^{\circ} 51^{\prime} \mathrm{E}\right.$, 수심 $\left.3600 \mathrm{~m}\right)$ 에서 MIS 3 동안에 탄 산염의 함량이 높은 세 구간들이 각각 D-O 사건들의 아 간빙기(interstadial) $8,12,14$ 에 대응된다고 제안하였다
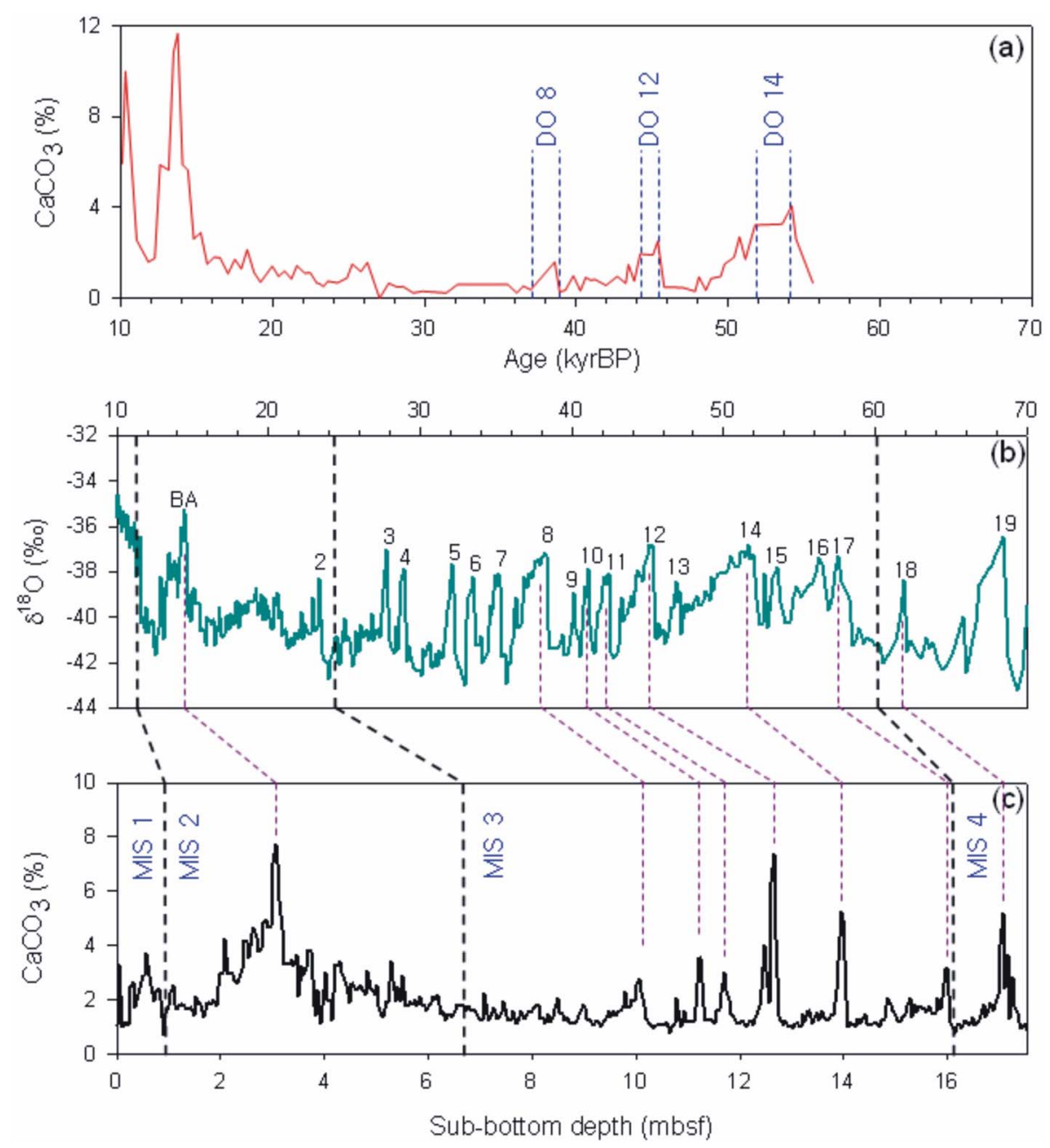

Fig. 4. (a) Occurrence of Dansgaard-Oeschger(D-O) events in core GC-11 (modified from Gorbarenko et al. 2005). (b) The $\delta^{18} \mathrm{O}$ stratigraphy of GISP 2 with the interstadial numbers of D-O events. (c) $\mathrm{CaCO}_{3}$ variation of core MR06-04 PC23A and correlation to D-O events. 
(Fig. 4a). 탄산염 함량이 높은 구간들에서 상대적으로 많 은 수의 부유성 유공충이 발견되었고, 부유성 유공충과 저 서성 유공충의 산소동위원소의 값도 상대적으로 낮게 측 정되었다고 설명하였다. 이들 구간에 알라스카 해류를 선 호하는 종들이 증가한 것은 온난한 수괴에서 서식하는 규 조들의 증가를 설명할 수 있다. 그 결과, Gorbarenko et al.(2005)은 MIS 3 시기동안 탄산염 피크가 나타나는 세 시기에는 베링해 남쪽의 표층수의 온도가 상승했고 기후 도 역시 온난했다고 해석하였다.

코아 MR06-04 PC23A에서도 MIS 3과 MIS 4 동안 탄 산염의 함량이 급격히 증가하는 구간들이 뚜렷하게 나타 난다(Fig. 3). 아직 정확한 코아의 연대를 결정할 수는 없 지만, 급격한 탄산염 함량의 증가 시기들은 D-O 사건들 중에 상대적으로 따뜻한 시기인 아간빙기들과 잘 대응되 는 것으로 생각된다(Fig. 4c). Gorbarenko et al.(2005)이 베링해 남쪽 지역에서 분석한 코아 GC-11에서는 3 개의 탄산염 피크가 보고된 반면(Fig. 4a), 이 연구의 코아 MR06-04 PC23A에서는 7개의 피크가 발견되었다(Fig. 4c). 이는 베링해의 남쪽해역보다 중앙지역의 대륙사면이 해빙의 영향에 의한 환경변화에 더 민감하기 때문으로 해 석할 수도 있지만, 코아 MR06-04 PC23A의 수심이 약 $1000 \mathrm{~m}$ 로 코아 $\mathrm{GC}-11$ (수심 3,600 m)에 비해 훨씬 얕은 지역에 위치하고 있기 때문에 탄산염보상수심에 의한 탄 산염 용해도가 상대적으로 약하기 때문이라고 해석할 수 있다. 앞 절에서 설명한 바와 같이, MIS 3이나 MIS 4 기 간 동안 해수면의 변화가 크지 않았기 때문에 희석 효과 나 용해 정도는 급격한 변화가 없었을 것으로 추측된다. 따라서, 이 시기의 탄산염 함량의 급격한 증가는 베링해 남쪽에서 Gorbarenko et al.(2005)이 제시하였던 부유성 유공충의 증가처럼, 온난한 표층 해수에서 탄산염을 구성 하는 생물기원 물질들의 공급이 갑작스럽게 증가했기 때 문으로 해석된다.

한 가지 특이한 점은 MIS 3의 후기에 그린랜드 빙하 코아(GISP 2)에서는 급격한 단주기 기후 변화인 D-O 사 건들이 계속해서 나타났지만(Fig. 4b), 코아 MR06-04 $\mathrm{PC} 23 \mathrm{~A}$ 의 탄산염 함량 변화는 그 이전의 변화와는 다르게 뚜렷한 피크가 발견되지 않는다(Fig. 4c). 이러한 특성들 은 베링해의 다른 지역(보우어스 해령: Okazaki et al. 2005; Gorbarenko et al. 2005; Brunelle et al. 2007, 움낙 고원: Okazaki et al. 2005)에서 시추한 코아들에서도 마 찬가지로 나타난다. Gorbarenko et al.(2005)은 MIS 3의 후기에 베링해 남쪽에는 냉수종인 부유성 유공충 $N$. pachyderma (s)가 점진적으로 증가했고, 이 종의 산소동위 원소 값이 점진적으로 커졌기 때문에, 이 기간이 더욱 추 운 환경 조건으로 변해가는 변환기라고 해석하였다. 그리 고 매우 낮은 탄산염 함량이 측정되었고 강한 용해를 받
은 흔적의 유공충 화석의 발견으로 베링해 해저에서의 탄 산염의 용해가 매우 강했음을 시사한다. 하지만, 저층에서 용해를 거의 받지 않는 생규소의 함량과 규조의 미화석도 이 기간에 점진적으로 낮아졌다고 보고되었다(Katsuki and Takahashi 2005; Okazaki et al. 2005; Brunelle et al. 2007). 이러한 특성은 당시의 표층해수의 일차생산성이 감 소했다는 것을 지시하는 것이다. Katsuki and Takahashi (2005)은 지난 마지막 빙하기동안 해빙이 베링해의 남쪽 부근까지 발달했었다고 보고하였다. 이 결과, 베링해의 북 쪽과 마찬가지로 표층해수의 생산성이 감소되었을 것이 다. 따라서 이 기간에 부유성 유공충의 수가 매우 적은 것 은 저층에서의 강한 용해와 더불어 표층에서의 낮은 생산 성에 기인한 것으로 해석되고, 탄산염의 함량이 매우 낮기 때문에 뚜렷한 D-O 사건들을 기록하기 어려웠을 것이다.

\section{5. 결 론}

(1) 베링해 중앙에 위치한 대륙사면에서 시추한 코아 MR06-04 PC23A의 탄산염 함량을 측정하여 빙하기-간빙 기의 고환경 변화를 복원하였다.

(2) 연대가 잘 정립된 코아 HLY02023JPC과의 퇴적상 비교와 방산충 L. nipponica sakaii와 A. setosa의 마지막 출현(Last Appearance Datum) 연대에 의해 코아 MR06$04 \mathrm{PC} 23 \mathrm{~A}$ 의 하부의 가능한 최대 연대(possible maximum age)가 약 6 만 5 천년으로 추정되었다.

(3) 후빙기 동안에 탄산염 함량이 가장 크게 증가하였으 며, 이러한 증가는 온난한 기후와 함께 증가된 융빙수에 의해 공급된 영양염의 증가로 표층 생산성이 크게 증가한 것과 관련이 있다.

(4) 빙하기(MIS 2) 동안에는 전반적으로 낮은 탄산염 함량을 보이고, 이는 추운 기후 동안 발달한 해빙의 증가 로 인하여 표층 생산성이 감소했기 때문으로 생각되다. 또 한, 이 기간 동안 낮아진 해수면에 의해 상대적으로 가까 워진 주변 육상에서 공급된 쇄설성 입자들의 희석효과도 기여했을 것이다.

(5) 마지막 빙하기(MIS 3, MIS 4)동안에 탄산염이 급격 하게 증가한 7 개의 구간들이 발견되었고, 이 시기들은 단 주기 기후변화인 D-O 사건들과 잘 대비된다. 그리고 MIS 3 의 후기에 D-O 사건들과 대비되는 탄산염 함량의 증가 가 나타나지 않는 것은 낮은 생산성과 높은 용해 작용 때 문으로 생각된다.

\section{사 사}

이 연구를 위해 베링해 시추퇴적물을 공급해 주신 동경 대학교의 Tada 교수님께 감사드리며 탐사기간 동안 수고해 
주신 R/V Mirai호의 승무원들에게도 감사를 드립니다. 자 료해석과 토의에 도움을 주신 Kota Katsuki 박사님께도 감사를 드리며, 논문을 심사해 주시고 훌륭한 지적을 아끼 지 않으신 익명의 두 심사위원님께 감사를 드립니다. 이 연구는 2008년도 정부재원으로 교육과학기술부 학술연구 조성사업(한국학술진흥재단 지원; KRF-2008-314-C00410) 및 국토해양부 국제공동연구사업 “지구환경변화 대책을 위 한 북서태평양과 주변해역의 제 4 기 후기 고기후변화와 북 태평양중층수의 역할 연구"의 일환으로 수행되었습니다.

\section{참고문헌}

Barnola, J.M., D. Raynaud, Y.S. Korotkevich, and C. Lorius. 1987. Vostok ice core provides 160,000-year record of atmospheric $\mathrm{CO}_{2}$. Nature, 329, 408-414.

Behl, R.J. and J.P. Kennett. 1996. Brief interstadial events in the Santa Barbara Basin, NE Pacific, during the past 60 kyr. Nature, 379, 243-246.

Bond, G.C. and R. Lotti. 1995. Iceberg discharges into the North Atlantic on millennial time scales during the last glaciation. Science, 267, 1005-1010.

Bond, G., W. Broecker, S. Johnsen, J. McManus, L. Labeyrie, J. Jouzel, and G. Bonani. 1993. Correlations between climate records from North Atlantic sediments and Greenland ice. Nature, 365, 143-147.

Brunelle, B.G., D.M. Sigman, M.S. Cook, L.D. Keigwin, G.H. Haug, B. Plessen, G. Schettler, and S.L. Jaccard. 2007. Evidence from diatom-bound nitrogen isotopes for subarctic Pacific stratification during the last ice age and a link to North Pacific denitrification changes. Paleoceanogr., 22, PA1215. doi:10.1029/2005PA001205.

Cook, M.S., L.D. Keigwin, and C.A. Sancetta. 2005. The deglacial history of surface and intermediate water of the Bering Sea. Deep-Sea Res. II, 52, 2163-2173.

Dansgaard, W., S.J. Johnsen, H.B. Clausen, D. Dahl-Jensen, N.S. Gundestrup, C.U. Hammer, C.S. Hvidberg, J.P. Steffensen, A.E. Sveinbjornsdottir, J. Jouzel, and G. Bond. 1993. Evidence for general instability of past climate from a 250-kyr ice-core record. Nature, 364, 218-220.

Fairbanks, R.G. 1989. A 17000-year glacio-eustatic sea-level record: Influence of glacial melting rates on the Younger Dryas event and deep-ocean circulation. Nature, 342, 637-642.

Favorite, F., A.J. Dodimead, and K. Nasu. 1976. Oceanography of the subarctic Pacific region, 1960-71. Bull. Intern. North Pacific Comm., 33, 1-187.

Feely, R.A., C.L. Sabine, K. Lee, F.J. Millero, M.F. Lamb, D.
Greeley, J.L. Bullister, R.M. Key, T.-H. Peng, A. Kozyr, T. Ono, and C.S. Wong. 2002. In situ calcium carbonate dissolution in the Pacific Ocean. Glob. Biogeochem. Cycles, 16, 1144. doi:10.1029/2002GB001866.

Gorbarenko, S.A. 1996. Stable isotope and lithologic evidence of Late-Glacial and Holocene Oceanography of the northwestern Pacific and its marginal seas. Quat. Res., 46, 230-250.

Gorbarenko, S.A., I.A. Basov, M.P. Chekhovskaya, J. Southon, T.A. Khusid, and A.V. Artemova. 2005. Orbital and millennium scale environmental changes in the southern Bering Sea during the last glacial-Holocene: Geochemical and paleontological evidence. Deep-Sea Res. II, 52, 2174-2185.

Griffin, J.M. 2003. Global Climate Change: The science, economics and politics. Edward Elgar, Cheltenham, UK. $280 \mathrm{p}$.

Hendy, I.L. and J.P. Kennett. 2000. Dansgaard-Oeschger cycles and the California Current system: Planktonic foraminiferal response to rapid climate change in Santa Barbara Basin, Ocean Drilling Program Hole 893A. Paleoceanogr., 15, 30-42.

Honjo, S. 1990. Particle fluxes and modern sedimentation in the polar oceans. p. 687-739. In: Polar oceanography, ed. by W.O. Smith. Academic Press, New York.

Hood, D.W. 1983. The Bering Sea. p. 337-373. In: Estuaries and enclosed Seas, ed. by B.H. Ketchum. Elsevier Scientific Pub. Co.

Itaki, T., N. Komatsu, and I. Motoyama. 2007. Orbital- and millennial-scale changes of radiolarian assemblages during the last 220 kyrs in the Japan Sea. Palaeogeogr. Palaeoclimatol. Palaeoecol., 247, 115-130.

Johnsen, S.J., H.B. Clausen, W. Dansgaard, N.S. Gundestrup, C.U. Hammer, and H. Tauber. 1995. The eem stable isotope record along the GRIP ice core and its interpretation. Quat. Res., 43, 117-124.

Katsuki, K. and K. Takahashi. 2005. Diatoms as paleoenvironmental proxies for seasonal productivity, sea-ice and surface circulation in the Bering Sea during the late Quaternary. Deep-Sea Res. II, 52, 2110-2130.

Khen, G.V. 1999. Hydrography of western Bering Sea shelf water. p. 161-176. In: Dynamics of the Bering Sea, ed. by T.R. Loughlin and K. Ohtani. Univ. Alaska Sea Grant, Fairbanks.

Kiefer, T., M. Sarnthein, H. Erlenkeuser, P.M. Grootes, and A.P. Roberts. 2001. North Pacific response to millennialscale changes in ocean circulation over the last $60 \mathrm{kyr}$. Paleoceanogr., 16, 179-189.

Martinson, D.G., N.G. Pisias, J.D. Hays, J. Imbrie, T.C. 
Moore, and N.J. Shackleton. 1987. Age dating and the orbital theory of ice ages: Development of a highresolution 0 to 300,000-year chronostratigraphy. Quat. Res., 27, 1-29.

Maykut, G.A. 1978. Energy exchange over young sea ice in the central Arictic. J. Geophys. Res., 83, 3646-3658.

Morley, J.J. and S.W. Robinson. 1986. Improved method for correlating late Pleistocene/Holocence records from the Bering Sea: Application of a biosiliceous/geochemical stratigraphy. Deep-Sea Res., 33, 1203-1211.

Niebauer, H.J. 1998. Variability in Bering Sea ice cover as affected by a regime shift in the North Pacific in the period 1947-1996. J. Geophys. Res., 103, 27717-27737.

Niebauer, H.J., N.A. Bond, L.P. Yakunin, and V.V. Plotnikov. 1999. An update on the climatology and sea ice of the Bering Sea. p. 29-59. In: Dynamics of the Bering Sea, ed. by T.R. Loughlin and K. Ohtani. Univ. Alaska Sea Grant, Fairbanks.

Okazaki, Y., K. Takahashi, H. Asahi, K. Katsuki, J. Hori, H. Yasuda, Y. Sagawa, and H. Tokuyama. 2005. Productivity changes in the Bering Sea during the late Quaternary. Deep-Sea Res. II, 52, 2150-2162.

Penrose, N. 1982. Biogenic sediments. p. 455-492. In: Marine Geology, ed. by J.P. Kennett. Prentice-Hall, INC., Englewood Cliffs.

Petit, J.R., J. Jouzel, D. Raynaud, N.I. Barkov, J.-M. Barnola, I. Basile, M. Bender, J. Chappellaz, M. Davis, G. Delaygue, M. Delmotte, V.M. Kotlyakov, M. Legrand, V.Y. Lipenkov, C. Lorius, L. Pepin, C. Ritz, E. Saltzman, and M. Stievenard. 1999. Climate and atmospheric history of the past 420,000 years from the Vostok ice core, Antarctica. Nature, 399, 429-436.

Sancetta, C. 1983. Effect of Pleistocene glaciation upon oceanographic characteristics of the North Pacific Ocean and Bering Sea. Deep-Sea Res., 30, 851-869.

Sancetta, C., L. Heusser, L. Labeyrie, S.A. Naidu, and S.W. Robinson. 1985. Wisconsin-Holocene paleoenvironment of the Bering Sea: Evidence from diatoms, pollen, oxygen isotopes and clay minerals. Mar. Geol., 62, 5568

Scipps Institution of Oceanography. 1973. Initial reports of the deep sea drilling project, Vol. 19, National Science Foundation, Washington (US Goverment Printing Office). 913 p.

Stabeno, P.J., J.D. Schumacher, and K. Ohtani. 1999. The physical oceanography of the Bering Sea. p. 1-28. In: Dynamics of the Bering Sea, ed by. T.R. Loughlin and K. Ohtani. Univ. Alaska Sea Grant, Fairbanks.

Takahashi, K. 1998. The Bering and Okhotsk Seas: Modern and paleoceanographic changes and gateway impact. $J$. Asian Earth Sci., 16, 49-58.

Takahashi, K. 2005. The Bering Sea and paleoceanography. Deep-Sea Res. II, 52, 2080-2091.

Taylor, K.C., G.W. Lamorey, R.B. Doyle, R.B. Alley, P.M. Grootes, P.A. Mayewski, J.W.C. White, and L.K. Barlow. 1993. The 'flickering switch' of late Pleistocene climate change. Nature, 361, 432-436.

Received Mar: 3, 2008 Accepted Jul. 7, 2008 